\title{
Determinants of feedlot adoption by beef cattle farmers in the state of São Paulo
}

\author{
Marcelo José Carrer ${ }^{1}$, Hildo Meirelles de Souza Filho', Marcela de Mello Brandão Vinholis² \\ 1 Universidade Federal de São Carlos, São Carlos, SP, Brasil. \\ ${ }^{2}$ Embrapa Pecuária Sudeste, São Carlos, SP, Brasil.
}

\begin{abstract}
The objective of this study was to identify the factors determining the adoption of feedlot by beef cattle farmers in the state of São Paulo, Brazil. For this purpose, primary data were collected among a sample of 84 farmers. The data were analyzed using descriptive statistics and a logit model. The analysis showed that the variables which increase the likelihood of adoption of feedlot by farmers are: scale of production, average price received, participation in farming associations, training, technical assistance and distance from the slaughter plant. Finally, measures for the formulation of public policies and private strategies were presented aiming at a more efficient use of production factors and, consequently, gains in productivity by beef cattle farmers.
\end{abstract}

Key Words: technology adoption, productivity, public policies

\section{Introduction}

The Brazilian beef cattle farming is marked by its great diversity and technological heterogeneity. While some producers are characterized by the adoption of capitalintensive production systems and high rates of productivity per area and/or per animal, others adopt extensive systems with low technical efficiency (Zylbersztajn \& Machado Filho, 2003; Souza Filho et al., 2010). This heterogeneity has been historically justified by the abundance of available land for production and by the absence of economic and institutional pressures to increase the efficiency of production factors. However, this scenario has quickly changed. Since the 1990s, rising prices for arable land have been observed along with a growing presence of Brazilian beef on the international market. In order to remain competitive in more demanding markets, it became necessary to obtain products with a higher level of standardization and better quality. Consequently, more capital-intensive production systems with higher productivity have been diffused. In addition, there has been a growth in restrictions concerning the encroachment of beef cattle production in natural forests and/or areas of environmental preservation. This new scenario has pointed to the need to continue to intensify production systems by adopting technologies capable of increasing the efficiency of production factors and, consequently, the competitiveness of beef cattle farmers.

According to several studies (Peixoto et al., 1989; Wedekin \& Amaral, 1991; Restle, 1999; Cezar et al.,
2005), feedlots present the highest technological intensity of any production system in Brazil. In this system, the animals are confined during the finishing phase for a period of 60 to 120 days, depending on the weight of the animals at entry and the level of technological intensification of the feedlot.The main objective of this system is to optimize animal weight gain, in order to reduce the production cycle and increase the efficiency per area and per animal. Despite the importance of this production system to increase the productivity of production factors, to reduce impacts on natural resources and to deliver better quality animals, relatively few farmers have adopted feedlots. According to data from the Census of Agriculture (2006), only $10.1 \%$ of beef cattle farms in the State of São Paulo have adopted feedlot. In Brazil, only $4.7 \%$ of beef cattle farms adopted this production system (IBGE, 2006). Thus, considering that the diffusion of feedlots is desirable, the following question can be raised: which factors could promote the diffusion of the feedlot system?

In light of this context, the main objective of the present study was to test hypotheses of factors that determine the adoption of the feedlot system. An empirical investigation was held among beef cattle farmers in the state of São Paulo. The study takes on particular importance, since, despite the importance of technological intensification in beef cattle production in Brazil, no recent studies have been conducted to analyze the determinants of the adoption of intensive production systems. 
The section subsequent to this introduction provides information on material and methods, beginning with a review of empirical studies on possible determinant factors of the adoption of agricultural technologies. From this review, eight hypotheses are raised on the adoption of feedlot system. Additionally, the section provides information on the sample and the statistical modeling. The following two sections present the statistical results and discussion on the determinants of adoption. The findings and their implications for policies are presented in the conclusions.

\section{Material and Methods}

Various studies have analyzed the adoption of technology in agriculture and livestock raising (Feder et al., 1985; Feder \& Umali, 1993; Souza Filho et al., 1998; Doye et al., 2000; Vicente, 2002; Silva \& Teixeira, 2002; Abdulai \& Huffman, 2005; Monte \& Teixeira, 2006; SouzaMonteiro \& Caswell, 2009; Pereira et al., 2010; Silva et al., 2011; Souza Filho et al., 2011). In general, three groups of variables have been identified in the literature as determinants for the adoption of technology by farmers. The first group is based on the characteristics of the farmer, such as: formal education, income, age, participation in cooperatives and farming associations, participation in informal groups promoting commercialization and exchange of information, participation in courses and lectures, experience in the field, level of access to and use of information and risk aversion. The second group is related to the characteristics of rural properties and business. In this group, the following variables are considered: scale of production, profitability, proximity to markets, diversification of production, financial leveraging, forms of commercialization of inputs and rural products, and physical and environmental conditions of the farm. The third group of variables consists of systemic factors, primarily: access to public policies (rural credit, minimum price policies, etc.), level of dissemination of information on existing technology and availability of skilled labor, etc. In this sense, eight variables were constructed in order to explain the decision, made by farmers in the study sample, whether or not to adopt the feedlot system. The construction of the variables and the formulation of the hypotheses are described below.

Scale of production (SP): variable measured as the total number of animals sold for slaughter in the year 2010 . In the literature, a positive relationship is assumed between the size of production and the adoption of technology by rural producers (Feder et al., 1985; Abdulai \& Huffman,
2005; Souza-Monteiro \& Caswell, 2009; Silva et al., 2011; Souza Filho et al., 2011). In general, large-farm owners have greater access to financial resources, lower average fixed costs and greater bargaining power in negotiations for the purchase of inputs and sale of farm products. All of the factors mentioned can contribute to the adoption of technology. In the present study, it is expected that the chance of the farmer adopting a feedlot system increases along with the number of animals sold for slaughter.

Average price received $(\mathrm{P})$ : the average price received was measured as the average price per arroba (unit of measure equivalent to $15 \mathrm{~kg}$ ) received by the farmer at the time of sale of the animals in 2010. Studies have proven that the relationship between average price received and the adoption of technology by farmers is positive (Monte \& Teixeira, 2006; Pereira et al., 2010). In this study, it is expected that the as the average price received by the farmer increases, the chance of adopting a feedlot production system also increases.

Technical assistance (TA): a dummy variable is used to determine whether the farmer received technical assistance, assuming a value of 0 for farmers that do not receive technical assistance and 1 for those who do. Technical assistance is an important way of propagating information about existing production technologies (Souza Filho et al., 2011). Moreover, technical assistance plays an important role in the efficient use of production factors, with consequent gains in productivity, production and technical efficiencies. Empirical studies have proven the positive effect of technical assistance on the adoption of technologies by farmers (Feder et al., 1985; Vicente, 2002; Abdulai \& Huffman, 2005). In a literature review on determinants of technology adoption by farmers in different countries, Feder \& Umali (1993) proved that extension services by the government are effective in fostering technology adoption and increasing social welfare. It is hypothesized that farmers that receive technical assistance are more likely to adopt feedlot systems.

Degree of financial leveraging (LEV): variable measured as the total rural credit divided by the production costs of the farmer in 2010. Rural credit is an important tool for encouraging the adoption of technology by farmers. This instrument reduces the budget constraint of farmers, enabling investments in production and the adoption of technology. However, farmers with a higher degree of financial leveraging are exposed to more risk, which, in turn, can inhibit the adoption of new technology. Empirical studies have found a positive relationship between the use of rural credit and the adoption of technology (Abdulai \& Huffman, 2005; Pereira et al., 2010). In the present study, 
a positive relationship between the degree of financial leveraging and the adoption of feedlot systems by cattle farmers is also expected.

Participation in farming associations (ASS): the dummy variable takes a value of 1 when the farmer participates in farming associations and 0 if otherwise. Participation in farming associations is a proxy for the social capital of farmers. It is assumed that farmers that participate in farming associations have greater access to information and share information of extreme importance for the performance of the activity. These farmers are more likely to share experiences through information networks and learn about new production and management techniques. Various studies have found a positive relationship between participation in farming associations (proxy for social capital) and the adoption of technology by farmers (Souza Filho et al., 1998; Doye et al., 2000; Monte \& Teixeira, 2006; Souza-Monteiro \& Caswell, 2009; Pereira et al., 2010). It is hypothesized that farmers that participate in farming associations are more likely to adopt feedlot systems.

Schooling (SCH): measured by the number of years of formal education the farmer has undergone. This variable aims to measure the human capital of the farmer and, therefore, is directly related to the capacity of the farmer to capture, store and process information. Farmers with more formal education may have greater management skills and be more apt to identify and adopt new technologies. Studies have confirmed the importance of the level of education for the adoption of technology by farmers (Abdulai \& Huffman, 2005; Pereira et al., 2010). In the present study, a positive relationship between the level of education of the farmers and the adoption of a feedlot system is expected.

Training (TR): the dummy variable takes a value of 1 for farmers and their respective managers and employees who frrequently participate in lectures, symposiums, congresses and courses related to rural production; and 0 otherwise. In addition to formal education, the level of training and qualification of the farmer and his employees can be important in determining adoption of production technologies. Farmers who frequently participate in technical courses, lectures and symposiums have access to important technical information on new production technologies and on the possible results of these technologies. In addition, farmers with qualified employees may present an advantage over farmers without skilled labor, such qualification being a possible facilitator in the process of adopting new production technologies. Studies have identified a positive relationship between the level of training of the farmer and his employees and the adoption of production technologies in farming (Monte \& Teixeira, 2006; Pereira et al., 2010;
Silva et al., 2011). A positive relationship between the level of training and qualification of the farmer and his employees and the adoption of feedlot systems is expected.

Proximity to slaughter plant (PA): the variable proximity to slaughter plant was measured by counting the number of export meat processing plants within a $100 \mathrm{~km}$ radius from the rural property. Farmers located in regions with processing plants, highways, developed services and markets have a greater chance of adopting new technologies and exploiting their resources than those located in frontier regions that do not possess infrastructure and consumer markets (Feder \& Umali, 1993; Abdulai \& Huffman, 2005; Souza Filho et al., 2011). It is hypothesized that farmers located near export meat processing plants are more likely to adopt feedlot systems.

The data used in the present study were obtained from a field study, in which 84 cattle farmers in the state of São Paulo were interviewed. Of this total, 44 had adopted the feedlot system and 40 had not. As a whole, these producers owned 189 rural properties in the state. The interviews were held in person, in a structured manner, throughout the period from January to September 2011. The data collected refer to the year 2010. The cattle farmers who took part in the sample of this study are located in 10 mesoregions of the state of São Paulo (Table 1). The sample was designed to represent the widest range of production systems (feedlot, semi-feedlot, extensive grazing with supplementation, extensive grazing without supplementation, etc.) and commercialization mechanisms (spot market, future market, future contracts, etc.), as well as the different characteristics existing among the producers and rural properties.

Means and standard deviations of some variables were calculated for each sub-sample of adopters and nonadopters of feedlot. The objective was to test hypotheses on the differences of the two sub-samples for those variables. Student's t test was performed, assuming normal distribution and the same variance for both sub-samples (Barbetta, 2011).

Table 1 - Geographic distribution of the sample of beef cattle farmers used in the present study

\begin{tabular}{lcc}
\hline Mesoregion & No. of cattle farmers & \% of total \\
\hline Araçatuba & 19 & 22.62 \\
Bauru & 13 & 15.47 \\
Marília & 5 & 5.95 \\
Presidente Prudente & 17 & 20.24 \\
Ribeirão Preto & 12 & 14.28 \\
São José do Rio Preto & 13 & 15.48 \\
Others & 5 & 5.95 \\
Total & 84 & 100.00 \\
\hline
\end{tabular}


Thus, the following hypothesis test was performed:

$$
\begin{aligned}
& H_{0}: \mu_{1}=\mu_{2} \\
& H_{1}: \mu_{1} \neq \mu_{2}
\end{aligned}
$$

in which $\mu_{1}$ is the mean of the response variable of the sample of farmers who adopted feedlot and $\mu_{2}$ is the mean of the response variable of the sample of farmers who did not. The level of $5 \%(\alpha=0.05)$ significance was adopted. Thus, $\mathrm{H}_{0}$ is rejected when $\mathrm{P} \leq 0.05$.

For binary explanatory variables ( 0 or 1 values), the chi-square test was performed. In these cases, the chi-square shows whether the differences between proportions are statistically significant (Barbetta, 2011). The following hypotheses were tested: $\mathrm{H}_{0}$ : the frequency distributions are the same for both groups; $\mathrm{H}_{1}$ : the frequency distributions of the response variable are not the same.

The 5\% significance level was also adopted in the chi-square test.

To test hypotheses for the determinant factors for feedlot adoption by beef cattle farmers, a logit model was used (Greene, 2003). Regarding the decision to adopt or not adopt this production system, we can assume that the farmer considers the marginal advantages and disadvantages of adoption. As the parameters of this decision are not generally observable, for each rural property $i$, we can define a latent variable, $y^{*}$, as:

$y_{i}^{*}=\beta^{\prime} X i+u_{i} i=1, \ldots, N$

in which $X$ denotes a set of explanatory variables. The observed pattern of adoption can be described by a dummy variable, $y$, such that $y_{i}=1$ if producer $i$ adopts the feedlot system and $y_{i}=0$ if he does not. These observed values of $y$ are related to $y^{*}$ as follows:

$y_{i}=1$ if $y_{i}^{*}>0$

$y_{i}=0$ otherwise

and

$$
\begin{aligned}
\operatorname{Pr}\left(y_{i}=1\right) & =\operatorname{Pr}\left(y_{i}^{*}>0\right)=\operatorname{Pr}\left(u i>-\beta^{\prime} X i\right)=1-F\left(-\beta^{\prime} X i\right) \\
& =F\left(\beta^{\prime} X i\right)
\end{aligned}
$$

in which $F$ is the cumulative distribution function for $u$ and an asymmetric distribution is assumed. Using maximum likelihood procedures, estimates of $\beta$ can be obtained. For the logit model, a logistic cumulative distribution function is assumed:

$$
\begin{aligned}
\operatorname{Pr}\left(\mathrm{y}_{i}\right. & =1)=\frac{e^{\beta X}}{1+e^{\beta X}} \\
& =\Lambda\left(\beta^{\prime} X\right)
\end{aligned}
$$

in which $\Lambda$ denotes the logistic cumulative distribution function.

The entire statistical analysis was conducted using Statistica 10.0 software.

\section{Results}

For the continuous variables, the test of comparison of means was statistically significant, at a $5 \%$ significance level, for: scale of production (SP) (Student's t; $\mathrm{P}=0.01$ ), and average price received $(\mathrm{P})$ (Student's t; $\mathrm{P}=0.04$ ). The cattle farmers who adopted feedlots (Group 1) presented, on average, a larger production scale than cattle farmers who did not adopt feedlots (Group 2) (Table 2). The average price received by the cattle farmers who adopted feedlots was also greater than the average price received by those who did not adopt this production system - average R $\$ 92.19$ for Group 1 and $\mathrm{R} \$ 87.52$ for Group 2. It is important to note that, although the cattle farmers from Group 1 presented a higher degree of leveraging in their business and had, on average, more schooling than the cattle farmers of Group 2, the means of these variables do not present statistically significant differences at the 5\% level.

For the dummy variables, the difference of frequency test was statistically significant, at a $5 \%$ significance level, for: technical assistance (TA) (chi-square; $\mathrm{P}=0.03$ ); participation in farming associations (ASS) (chi-square; $\mathrm{P}=0.02$ ); and training (TR) (chi-square; $\mathrm{P}=0.03$ ). The interpretation of the means of these variables can proceed in the following manner. Among the cattle farmers who adopted feedlots, $91 \%$ received technical assistance, while $65 \%$ of the cattle farmers who did not adopt feedlots received technical assistance. Participation in farming associations was greater for the cattle farmers of Group 1, reaching $38 \%$ in this subsample, while only $15 \%$ of the cattle farmers of Group 2 participated in associations. With regard to training and qualification of cattle farmers and their employees, $86 \%$ of those interviewed from Group 1

Table 2 - Descriptive statistics of the variables for the two groups of farmers

\begin{tabular}{lccccc}
\hline & $\begin{array}{c}\text { Group 1: adopted feedlots } \\
\text { 44 producers }\end{array}$ & & $\begin{array}{c}\text { Group 2: did not adopt feedlots } \\
\text { 40 producers }\end{array}$ \\
\cline { 2 - 3 } \cline { 5 - 6 } \cline { 5 - 6 } & Mean & $\begin{array}{c}\text { Standard } \\
\text { deviation }\end{array}$ & & Mean & $\begin{array}{c}\text { Standard } \\
\text { deviation }\end{array}$ \\
\hline SP & $7,030.66$ & $11,970.50$ & & 936.82 & $1,170.22$ \\
P & 92.19 & 6.93 & & 87.52 & 7.93 \\
TA & 0.91 & 0.29 & & 0.65 & 0.48 \\
LEV & 0.21 & 0.21 & & 0.17 & 0.18 \\
ASS & 0.38 & 0.49 & & 0.15 & 0.36 \\
SCH & 15.79 & 2.54 & & 15.22 & 2.65 \\
TR & 0.86 & 0.34 & & 0.52 & 0.51 \\
PA & 1.52 & 1.19 & & 1.83 & 1.36 \\
\hline
\end{tabular}

SP - scale of production (number of animal sold for slaughtering); P - average price received $(\mathrm{R} \$ * 15 \mathrm{~kg}$ of meat carcass sold); TA - technical assistance $(0$ or 1$)$; LEV - degree of financial leveraging (loan from rural credit $(\mathrm{R} \$) /$ production costs (R\$)); ASS - participation in farming associations (0 or 1); $\mathrm{SCH}$ - schooling (number of years); TR - training (0 or 1); PA - proximity to slaughter plant (number of export beef plants).

*R\$ - Brazilian Reais (BRL) 
declared that they participated in technical courses and lectures, while $52 \%$ of those interviewed from Group 2 said they participated.

Regarding the results obtained from the estimation of the logit model (Table 3), the dependent variable is a dummy, $y$, in which $y_{i}=1$ if farmer $i$ adopts a feedlot system and $y_{i}=0$ if he does not. The likelihood ratio (LR) test allows for rejection of the joint hypothesis in which all coefficients of the explanatory variables of the model are equal to zero. The model can then be used to explain the determinants of adoption of feedlots by the farmers. The correlation between the explanatory variables was low enough to avoid multicollinearity problems. The coefficients of six of the eight explanatory variables used in the model were statistically significant, namely: scale of production (SP), average price received (P), technical assistance (TA), participation in farming associations (ASS), training (TR) and proximity to slaughter plant (PA). The model presented excellent goodness of fit, in which $84.01 \%$ of the farmers from Group 1 (adopted feedlot system) and $80 \%$ of the farmers from Group 2 (did not adopt feedlot system) were correctly predicted by the model.

\section{Discussion}

This section provides a discussion on the six adoption determinants found in the last section. It was found that the higher the scale of production (SP), the greater the chance of adoption of a feedlot production system. This result corroborates the hypothesis raised for this variable and is in agreement with other empirical studies. Beef cattle farmers with larger scales of production have greater bargaining power when negotiating the purchase of inputs (feed, backgrounding steers, medicine, etc.) and are more able to reduce average fixed costs associated with the adoption of feedlots. These factors contribute to the adoption of feedlots by large farm owners. For small-scale farmers to overcome this barrier, farmer organizations or informal networks for the purchase of inputs and sale of animals are suggested. In fact, it was observed in the fieldwork that small-scale farmers who adopt feedlot systems organize themselves into informal groups to purchase larger quantities of inputs.

The variable average price received $(\mathrm{P})$ also presented a positive impact on the probability of adoption of feedlots, as expected. This result was similar to that found in other studies about technology adoption carried out with farmers in Brazil, showing that farmers that receive higher prices have incentives to adopt new technologies. In fact, the production costs for feedlots are higher, requiring higher prices to make the activity economically viable. Furthermore, in the case of feedlots, the supply of fattened animals occurs mainly during the off-season period for the animals fattened on pasture, when the price is normally higher.

Another variable that behaved as expected was technical assistance (TA), which presented a positive effect on the adoption of feedlot. This result corroborated the findings of other technologiy adoption studies. In terms of public policy proposal, the supply of technical assistance and rural extension services are policies likely to achieve positive results. In terms of private strategy, investments in technical assistance are also important.

The variable training (TR) is also positively associated with the adoption of feedlots by famers. This variable covers two important factors: level of training of the farmer/manager of the property and the qualification level of employees. Thus, it becomes evident that these factors contribute to the adoption of feedlots. Farmers that invest in their own qualifications and in the upgrade of their employees are more apt to adopt new production technologies. In this

Table 3 - Coefficient estimates of the logit model for analysis of the determinants of adoption of feedlot systems by the beef cattle farmers interviewed

\begin{tabular}{|c|c|c|c|}
\hline Variable & Coefficient & Wald Statistic & P-value \\
\hline Constant** & -6.10850 & 2.889891 & 0.0891 \\
\hline Scale of production* & 0.00038 & 3.971239 & 0.0463 \\
\hline Average price received $* *$ & 0.06901 & 2.793779 & 0.0946 \\
\hline Technical assistance* & 1.19859 & 5.666516 & 0.0172 \\
\hline Degree of financial leveraging & -1.65907 & 0.996228 & 0.3182 \\
\hline Participation in farming associations** & 0.65148 & 3.133629 & 0.0766 \\
\hline Schooling & -0.70651 & 2.2875869 & 0.1304 \\
\hline Training* & 0.933022 & 6.0481021 & 0.0139 \\
\hline Proximity to slaughter plant** & -0.563877 & 3.8409164 & 0.0500 \\
\hline Log - L & -35.26 & Nagelkerke $\mathrm{R}^{2}$ & 0.5602 \\
\hline LR Statistic ( $8 \mathrm{gl})$ & 45.73 & Correct estimates Group 1 & $84.01 \%$ \\
\hline P-value (LR statistic) & 0.00 & Correct estimates Group 2 & $80 \%$ \\
\hline
\end{tabular}

* Significant at $5 \%$.

** Significant at $10 \%$

LR - likelihood ratio 
regard, public policies for upgrading rural labor have the potential to increase the efficiency of production factors and, consequently, farming productivity.

Similarly, participation in farming associations (ASS) also presented a positive impact on the likelihood of farmers adopting feedlots. These farmers share information and experiences on production and management techniques, which is important to the identification of opportunities and to the adoption of new production techniques. Other empirical studies have shown similar results for this variable. It is important to stress that there are important beef cattle associations in the state of São Paulo, which, according to the results of the present study, play a fundamental role in the beef cattle supply chain.

Finally, the variable proximity to slaughter plant (PA) presented an unexpected result. It was expected that a higher number of export meat processing plants near farms would increase the probability of adoption of feedlots. A possible explanation for this contradictory result lies in the fact that the state of São Paulo has a large number of export beef processing plants, as well as good shipping infrastructure throughout the state. Therefore, anywhere within the state of São Paulo, the farmer is always in a satisfactory position to ship production to an export beef processing plant. In addition, there are small beef processing plants and municipal slaughterhouses that, despite not exporting their production, make use of animals from feedlots to meet the needs of the domestic market.

\section{Conclusions}

In view of the recent changes in institutional and economic contexts that affect the production of beef cattle, technological intensification in production has become increasingly important. In the state of São Paulo, the need for technological intensification is even greater due to the high costs (explicit costs and opportunity costs) associated with the use of land. Feedlot systems for finishing animals have been shown to be a way of keeping farmers in business and, ultimately, increasing the production of beef. The results for the variables in the present study are in agreement with various studies on the adoption of technology in farming, which reinforces the importance of these variables in the process of technological intensification. Public policies aimed at greater efficiency in the use of production factors in beef cattle farming should consider investments and upgrade of rural labor (both operational and managerial), strengthening of organizational arrangements between farmers (associations, cooperatives, informal commercialization networks, etc.) and provision of technical assistance and rural extension services. The importance of public policy suggestions resides on the fact that the quicker a superior technology is diffused, the greater the improvement of social welfare, since higher rural income and higher levels of production can be sooner enjoyed. Regarding private strategies, small cattle farmers should increase their level of horizontal and vertical organization, as well as further upgrade both labor and management and expand the use of technical assistance.

\section{Acknowledgments}

This paper was funded by São Paulo Research Foundation (FAPESP), in the form of Research Assistance (2010/02787-0).

\section{References}

ABDULAI, A.; HUFFMAN, W.E. The diffusion of new agricultural technologies: the case of crossbred-cow technology in Tanzania. American Journal of Agricultural Economics, v.87, n.3, p.645-659, 2005.

BARBETA, P.A. Estatística aplicada às ciências sociais. Florianópolis: Editora UFSC, 2011.315p.

CEZAR, I.M.; QUEIROZ, H.P.; THIAGO, L.R.L.S. et al. Sistemas de produção de gado de corte no Brasil: uma descrição com ênfase no regime alimentar e no abate. Campo Grande, MS: Embrapa Gado de Corte, 2005. 40p. (Documentos/ Embrapa Gado de Corte, 151).

DOYE, D.; JOLLY, R.; HORNBAKER, R. et al. Case studies of farmers' use of information systems. Review of Agricultural Economics, v.22, n.2, p.566-585, 2000.

FEDER, G.; JUST, R.E.; ZILBERMAN, D. Adoption of agricultural innovations in developing countries: a survey. Economic Development and Cultural Change, v.33, n.2, p.255-298, 1985.

FEDER, G.; UMALI, D. The adoption of agricultural innovations: a review. Technological Forecasting and Social Change, v.43, p.215-239, 1993.

GREENE, W. Econometric analysis. 5.ed. New Jersey: Prentice Hall, 2003. 1024p.

INSTITUTO BRASILEIRO DE GEOGRAFIA E ESTATÍSTICA IBGE. Censo agropecuário 2006. Available at: $<$ www.sidra.ibge. gov.br> Accessed on: Mar. 5, 2012.

MONTE, E.Z.; TEIXEIRA, E.C. Determinantes da adoção da tecnologia de despolpamento na cafeicultura. Revista de Economia e Sociologia Rural, v.44, n.2, p.201-217, 2006.

PEIXOTO, A.M.; HADDAD, C.M.; BOIN, C. et al. O confinamento de bois. 3.ed. São Paulo: Globo, 1989. 172p.

PEREIRA, M.W.G.; TEIXEIRA, E.C.; LIMA, J.E. Adoção seqüencial de tecnologia pós-colheita aplicada à cafeicultura em Viçosa (MG). Revista de Economia e Sociologia Rural, v.48, n.2, p.381-404, 2010.

RESTLE, J. Confinamento, pastagens e suplementação para produção de bovinos de corte. Santa Maria: Universidade Federal de Santa Maria, 1999. 258p.

SILVA, C.B.; MORAES, M.A.F.D.; MOLIN, J.P. Adoption and use of precision agriculture technologies in the sugarcane industry of São Paulo state, Brazil. Precision Agriculture, v.12, p.67-81, 2011.

SILVA, S.P.; TEIXEIRA, E.C. Determinantes da adoção da tecnologia "plantio direto" na cultura da soja em Goiás. Revista de Economia e Sociologia Rural, v.40, n.2, p.305-326, 2002. 
SOUZA FILHO, H.M.; BUAINAIN, A.M.; SILVEIRA, J.M.F.J. et al. Condicionantes da adoção de inovações tecnológicas na agricultura. Cadernos de Ciência \& Tecnologia, v.28, n.1, p.223-255, 2011.

SOUZA FILHO, H.M.; ROSA, F.T.; VINHOLIS, M.M.B. Análise da competitividade da cadeia produtiva da carne bovina do estado de São Paulo. Informações Econômicas, v.40, n.3, p.16-28, 2010.

SOUZA FILHO, H.M.; YOUNG, T.; BURTON, M. Factors influencing the adoption of sustainable agricultural technologies: evidence from the State of Espírito Santo, Brazil. Technological Forecasting and Social Change, v.60, n.2, p.97-112, 1998.
SOUZA-MONTEIRO, D.M.; CASWELL, J.A. Traceability adoption at the farm level: an empirical analysis of the portuguese pear industry. Food Policy, v.34, n.1, p.94-101, 2009.

VICENTE, J.R. Pesquisa, adoção de tecnologia e eficiência na produção agrícola. São Paulo: APTA/SAAESP, 2002. 150p

WEDEKIN, V.P.; AMARAL, A.M.P. Confinamento de bovinos em 1991. Informações Econômicas, v.21, n.7, p.9-18, 1991.

ZYLBERSZTAJN, D.; MACHADO FILHO, C.A.P. Competitiveness of meat agri-food chain in Brazil. Supply Chain Management: An International Journal, v.8, n.2, p.155-165, 2003. 